\title{
Dependency Rate and Savings: The African Evidence with Panel Data
}

\author{
Nicholas Apergis (Corresponding author) \\ Professor, Department of Banking \& Financial Management \\ University of Piraeus, Piraeus, Attiki, Greece \\ Tel.30-210-414-2429 E-mail: napergis@unipi.gr \\ Christina Christou (Assistant Professor) \\ Department of Banking \& Financial Management \\ University of Piraeus, Piraeus, Attiki, Greece \\ Tel. 30-210-414-2344Ｅ-mail: christou@unipi.gr
}

$\begin{array}{ll}\text { Received: October 18, } 2011 & \text { Accepted: November 2, } 2011 \quad \text { Published: February 16, } 2012 \\ \text { doi:10.5539/ijbm.v7n4p84 } & \text { URL: http://dx.doi.org/10.5539/ijbm.v7n4p84 }\end{array}$

\begin{abstract}
This study examines the impact of the age dependency ratio on domestic savings rates. We test this issue for 16 African countries using annual panel data. The empirical analysis was conducted using the panel unit roots, panel cointegration and panel causality tests. The empirical findings indicate evidence of panel cointegration. Furthermore, results from panel causality analysis reveal that dependency ratio causes savings rate negatively. Overall, our findings support the view that changes in non-working population size are important in explaining the future path of domestic savings rates in Africa.
\end{abstract}

Keywords: Savings, Dependency rates, Panel unit roots, Panel cointegration, Panel causality, African countries

\section{Introduction}

International comparative analysis of the savings behavior over the last three decades has shown that the world has witnessed a marked divergence in saving rates. While saving rates have risen steadily in East Asia and stagnated in Latin America, they have fallen in African economies (Loayza et al. 2000). Mwega (1997) finds evidence that savings rates in these economies are unambiguously lower, while the crucial factors that affect such rates are the dependency ratio, the level of per capita income, economic growth, and terms of trade. Deaton (1992) suggests that African countries' savings behavior is guided by rules of thumb, while short-term income changes seem to be the primary cause of savings attitudes. In addition, Ikhide (1996) and Nissanke and Aryeetey (1998) argue that savings mobility is weak because of certain institutional impediments, such as the low presence of formal institutions, e.g. an adequate number of bank offices, the fact that financial markets in Africa are highly fragmented, and high transaction costs for economic agents of trying to move across different segments.

These regional disparities have raised academic interest in the following question: why do saving rates differ so much across countries and time periods? This question has stimulated a large body of empirical works across the world. Among the various factors that are likely to play an important role in explaining savings, the demographic structure of the population has been viewed as one of the most crucial. The 'East Asian Miracle' is often attributed to the rapid demographic transition, which contributed to increasing the rates of national savings and economic growth by lowering fertility rates and changing the age composition of the population (Higgins and Williamson, 1997; Bloom and Williamson, 1998; Mason, 2001). A striking feature of most African countries is the age structure of their population. Their high fertility rates lead to high level of age dependency ratio. This has serious implications for domestic savings rates.

There are many reasons to believe that the dependency ratio is central for explaining differences in savings behavior and economic growth across countries. The theoretical underpinnings of this belief are based on the life-cycle hypothesis. The argument goes as follows. Economic agents have negative savings when young and have low or no income, positive savings during their productive years and, again, negative savings when they are old and retired (Modigliani, 1970). As children constitute a heavy charge for parents and do not contribute to production, an increase in their proportion in the population is expected to reduce the private savings rate (Leff, 
1969). Similarly, an increase in the proportion of elderly in the population is also expected to hamper the aggregate savings rate, since the retired are assumed to exercise negative saving. By contrast, increases in the dependency ratio may put significant upward pressure on government spending on health and education needed to improve the quality of life. This could involve a reduction in public savings if fiscal policies remained unchanged. Hence, the age structure of the population has a special role in explaining the overall national savings rates.

On empirical grounds, an extensive strand of literature has been performed to investigate the effect of dependency ratio on savings. Evidence is mixed across countries and methodologies. Studies using cross-country data have been more successful than time-series studies for individual countries in finding significant demographic effects. In particular, Leff (1969), Modigliani (1970), Graham (1987), Edwards (1996), Muradoglu and Taskin (1996), Kelley and Schimdt (1996), Masson et al. (1998), and Loayza et al. (2000) have found some evidence in favor of the life-cycle model. Moreover, some attempts have been undertaken at individual country level. Horioka (1997), Escobar and Cardenas (1998), Elbadawi and Mwega (2000), Thornton (2001), Prema-Chandra and Pnag-Long (2003), Serres and Pelgrin (2003) and Modigliani and Cao (2004) show that higher age dependency ratios are associated with lower saving rates. However, other studies including Goldberger (1973), Ram (1982), Husain (1995), Faruquee and Husain (1998), and Baharumshah et al. (2003) present cases in which the dependency ratio effect on savings may be insignificant or even positive.

The main objective of this study is to test whether the dependency rate has a positive or negative long-run effect on domestic savings rates for African countries, in which the life-cycle model may be less applicable, because of cultural peculiarities such as the uncertainty of income and the greater prevalence of intergenerational transfers within families. In most African countries, private transfers from children to aged parents are more common than in Europe and United-States (Nugent, 1985; Attias-Donfut, 1995, and Altonji el al., 1997), and such intergenerational transfers could mitigate the need for life-cycle saving, since child becomes an effective substitute for life-cycle savings. It is now widely recognized that savings play a crucial role in explaining differences in the economic performance between Africa and Southeast Asian countries. While its availability is not by itself a panacea for economic and social problems facing Africa, domestic savings is nevertheless believed to be a necessary requirement for financing Africa's domestic investment and economic and social development. Africa is estimated to lose a great deal of funds in domestic revenues through capital flight, tax evasion, the repatriation of profits by transnational corporations, high debt repayments and inadequate financial services. In addition, savings has long been repressed by controlled low interest rates and high inflation. These negative real interest rates have discouraged people from monetizing their savings using formal financial institutions. While many households have notable savings, these are being held in a non-financial form, i.e. livestock, stockpiles of goods for trading, grain, jewellery or construction material. Moreover, while foreign aid was supposed to complement domestic financial resources to boost growth efforts and assist countries to break away from poverty, it ended up dampening domestic savings. Given the fact that low domestic savings rates is a bottleneck to economic growth (Anoruo and Ahmad, 2001) and despite the economic reforms that many African countries attempted in the past (World Bank, 2002), these falling trends are not expected to improve in the near future, unless serious efforts are made to increase financial-sector outreach and create the conditions for proper financial intermediation.

In addition, it has been reported by some economists that the rationale of Africans is altered by social constraints, which impede savings and investment trends (Mahieu, 1990; Hugon, 1993). The support to dependents is organized within families and implies great amounts of financial private transfers. This analysis followed in this paper has certain novelties: First, it makes use of a new sample of African countries with respect to the dependency ratios and savings, while it makes use, for the first time in this literature, of the methodology of panel data to investigate the above relationship.

The remainder of this paper is organized as follows. Section 2 presents the data and the empirical results. Finally, section 3 offers a brief summary and gives some concluding remarks.

\section{Data}

The study uses time series annual data on gross domestic savings rates as share of GDP (S), the age dependency ratio (D), and real per capita GDP (Y). Gross domestic savings are calculated as GDP less final consumption expenses, i.e. total consumption. GDP is the sum of gross value added by all resident producers in the economy plus any product taxes and minus any subsidies not included in the value of the products. It is calculated without making deductions for depreciation of fabricated assets or for depletion and degradation of natural resources. The age dependency is defined here as the ratio of the population younger than 15 years and older than 64 years 
old to the population between 15 and 64 years old. It is a rough index of the dependency burden imposed by dependents (children and elderly). The sample includes 16 African countries, namely: Benin, Burkina Faso, Cameroon, Cote d'lvoire, Ghana, Kenya, Mali, Mauritania, Niger, Nigeria, Senegal, Sierra Leone, South Africa, Togo, Zambia and Zimbabwe. The sample size spans the period 1960-2005. All data is extracted from the 2008 World Development Indicators tapes of the World Bank (2008). Finally, the RATS (version 6.1) software assists the empirical analysis.

Table 1 reports some descriptive statistics of the two variables of interest. The most striking features to emerge are the low levels of savings rates in our sample. As indicated by the minimum, a number of countries have negative rates of saving for a number of years. Cote d'lvoire, Nigeria, South Africa and Zambia have the highest average savings rates of $22.93 \%, 20.09 \%, 24.84 \%$, and $22.18 \%$, respectively. The rates of domestic savings in the remaining countries have averaged less than $20 \%$ of GDP over the past four decades.

Overall, the average savings rates are lower than those of the fast growing Asian countries (see Husain, 1995; Baharumshah el at., 2003). Low levels of domestic savings in most African countries condemn them to an excessive reliance upon foreign capital, which makes them vulnerable to financial crises. Except for South Africa, the age dependency rate is over $80 \%$ in each of the countries under study. With such high dependency ratios, how can African countries achieve high level of savings rates? The correlation coefficients between the two variables show that the savings rate and the dependency ratio are positively related in 8 countries, and negatively linked in two countries. Correlation, however, does not say anything about cointegration and causality and, thus, leaves unsettled the debate concerning the short- and long-run effects of the age dependency rate on savings rate for African countries.

\section{Empirical results}

\subsection{Panel unit root tests}

Before we proceed with our empirical analysis, it is important to investigate the order of integration of the series using unit root tests. At the outset, the statistical properties of the savings ratio, the dependency ratio and the per capita income are examined by testing for the presence of unit roots. There are a variety of panel unit root tests, which include Maddala and Wu (1999), Hadri (2000), Levin et al. (LLC, 2002), Im et al. (IPS, 2003), and Carrion-i-Silvestre et al. (2005), among others. Consider the following autoregressive specification:

$$
y_{i t}=\rho_{i} y_{i t-1}+\delta_{i} X_{i t}+\varepsilon_{i t}
$$

where $i=1, \ldots, N$ for each country in the panel; $t=1, \ldots, T$ refers to the time period; $X_{i t}$ represents the exogenous variables in the model including fixed effects or individual time trend; $\rho_{i}$ are the autoregressive coefficients; and $\varepsilon_{i t}$ are the stationary error terms. If $\rho_{i}<1, y_{i t}$ is considered weakly trend stationary whereas if $\rho_{i}=1$, then $y_{i t}$ contains a unit root. The Hadri (2000), and Levin et al. (2002) panel unit root tests assume that the error terms, $\varepsilon_{i t}$, are independently and normally distributed random variables for all $i$ 's and $t^{\prime} s$ with mean zero and constant variance. This assumption implies that the coefficient of $y_{i t-1}$ is homogeneous across all cross-section units of the panel and individual processes are cross-sectionally independent. In the case of dynamic panel data models, the recognition of parameter heterogeneity is important in order to avoid potential biases which could emerge due to an improper specification.

- In light of parameter heterogeneity, the IPS panel unit root test is utilized which allows for heterogeneous autoregressive coefficients. Such heterogeneity could occur due to the different economic conditions and stages of economic development in each country. Im et al. (2003) suggest averaging the augmented Dickey-Fuller (ADF) unit root tests while allowing for different orders of serial correlation $\varepsilon_{i t}=\sum_{j=1}^{p_{i}} \varphi_{i j} \varepsilon_{i t-j}+u_{i t}$. Substitution of this expression into (1) yields

$$
y_{i t}=\rho_{i} y_{i t-1}+\sum_{j=1}^{p_{i}} \varphi_{i j} \varepsilon_{i t-j}+\delta_{i} X_{i t}+\varepsilon_{i t}
$$

where $p_{i}$ represents the number of lags in the ADF regression. The null hypothesis is that each series in the panel contains a unit root $\left(H_{0}: \rho_{i}=1 \forall_{i}\right)$. The alternative hypothesis is that at least one of the individual series in the panel is stationary $\left(H_{0}: \rho_{i}<1\right)$. Im et al. (2003) specify a $t$-bar statistic as the average of the individual ADF statistics as follows:

$$
t-b a r=\frac{1}{N} \sum_{i=1}^{N} \rho_{i}
$$

where $t_{\rho_{i}}$ is the individual t-statistic for testing $H_{0}: \rho_{i}=1 \forall_{i}$ from (3). The $t$-bar statistic is normally distributed under the null hypothesis with the critical values for given values of $N$ and $T$ provided by $\operatorname{Im}$ et al. 
(2003).

The LLC test allows heterogeneity of individual deterministic effects and heterogeneous serial correlation structure of the error terms assuming homogeneous first order autoregressive parameters. They also assume that both $\mathrm{N}$ and $\mathrm{T}$ tend to infinity but $\mathrm{T}$ increases at a faster rate, such that $\mathrm{N} / \mathrm{T} \rightarrow 0$. Thus, a procedure is developed that uses t-statistics of the estimator to evaluate the hypothesis that each individual time series contains a unit root against the alternative hypothesis that each time series is stationary. The test also makes use of the ADF regression methodology, with the $\mathrm{ADF}$ regression defined as:

$$
\Delta \mathrm{y}_{\mathrm{it}}=\alpha_{\mathrm{i}}+\gamma_{\mathrm{i}} \mathrm{y}_{\mathrm{i}, \mathrm{t}-1}+\sum_{\mathrm{j}=1}^{\mathrm{P}_{\mathrm{i}}} b_{i j} \Delta \mathrm{y}_{i, t-j}+\varepsilon_{\mathrm{it}}
$$

Moreover, the test implements a separate ADF regression for each country where the lag order is permitted to vary across individual countries. The appropriate lag order is chosen by allowing the maximum lag order and then uses the t-statistic for the coefficients of the lag terms to determine if a smaller lag order is preferred. Next, it runs two separate regressions, such as:

$$
\Delta \mathrm{y}_{\mathrm{it}}=\alpha_{\mathrm{i}}+\sum_{\mathrm{j}=1}^{\mathrm{P}_{\mathrm{i}}} b_{i j} \Delta \mathrm{y}_{i, t-j}+\mathrm{e}_{\mathrm{it}}
$$

And

$$
\mathrm{y}_{\mathrm{i}, \mathrm{t}-1}=\alpha_{\mathrm{i}}+\sum_{\mathrm{j}=1}^{\mathrm{P}_{\mathrm{i}}} b_{i j} \Delta \mathrm{y}_{i, t-j}+\mathrm{v}_{\mathrm{i}, \mathrm{t}-\mathrm{j}}
$$

and we save the residuals $\left(\mathrm{e}_{\mathrm{it}}\right.$ and $\left.\mathrm{v}_{\mathrm{i}, \mathrm{t}-\mathrm{j}}\right)$. We divide the both of saved residuals by the regression standard error of the regression for normalization purposes and, next, we run the regression,

$$
\mathrm{e}_{\mathrm{it}}=\rho \mathrm{v}_{\mathrm{i}, \mathrm{t}-\mathrm{j}}+\varepsilon_{\mathrm{it}}
$$

with the null hypothesis being $\mathrm{H}_{0}: \rho_{1}=\ldots=\rho_{\mathrm{n}}=\rho=0$ and the alternative hypothesis is $\mathrm{H}_{1}: \gamma_{1}=. .=\gamma_{\mathrm{n}}=\gamma<0$ for all $i$. LLC show that the asymptotic properties of the regression estimators are a mixture of properties derived for stationary panel data and properties derived in unit roots testing. This test seems to have certain limitations, such as that it depends seriously upon the independence assumption across individual regressions and hence not applicable if cross sectional correlation is present. In addition, a limitation is associated with the fact that the autoregressive parameters are considered being identical across the panel regressions (see the above null hypothesis). However, this null hypothesis makes sense under some cases. As Maddala and Wu (1999) point out, the alternative hypothesis is too strong to be valid in any empirical case.

Maddala and $\mathrm{Wu}$ (1999) offer a strategy that seems to overcome the limitations of both LLC and Im et al. tests. They suggest a non-parametric Fisher-type test, which is based on a combination of the p-values of the t-statistics for a unit root in each cross-sectional unit (the ADF test). Pooling on the basis of the p-value is a common practice in meta-analysis. More specifically, the testing approach has the advantage of allowing for as much heterogeneity across units as possible. Under the hypothesis that the test statistics are continuous, the significance of $p$-values is independent in a uniform manner, e.g. they uniform $(0,1)$ variables and $-2 \log p$ has a chi-squared distribution with two degrees of freedom. Using the additive property of the chi-squared variables, the statistic $\lambda=-2 \sum_{\mathrm{j}=1}^{N} \log p_{i}$ is constructed, which has a chi-squared distribution with $2 \mathrm{~N}$ degrees of freedom. The advantage of this test is it does not require an infinite number of groups to be valid, we do not have to assume that all groups must have the same type of non-stochastic components, $\mathrm{T}$ is not necessarily assumed to be the same for all the cross-section units, its critical values are not sensitive to the choice of lag lengths in the ADF regressions, and finally, it does not have to assume that none of the groups have a unit root under the alternative hypothesis.

The Carrion-i-Silvestre et al. (2005) test is associated with testing the residuals $(\varepsilon)$ from the above individual OLS regression (1). Given those residuals, a Lagrange multiplier (LM) statistic is constructed defined as: 


$$
\mathrm{LM}=1 / \mathrm{N}\left(\sum_{j=1}^{\mathrm{N}} \sum_{t=1}^{\mathrm{T}} \mathrm{S}_{\mathrm{it}}{ }^{2} / \mathrm{T}^{2} / \overline{\mathrm{u}}_{0}\right)
$$

where $S_{i t}$ denotes the cumulative sum of the residuals, $T$ is the number of time periods and $\bar{u}_{0}$ is the average of individual estimators of the residual spectrum at frequency zero.

It is defined as $\overline{\mathrm{u}}_{0}=\sum_{\mathrm{i}=1}^{\mathrm{N}} \mathrm{u}_{\mathrm{i} 0} / \mathrm{N}$. Under certain assumption the statistic: $\sqrt{\mathrm{N}}(\mathrm{LM}-\zeta) / \xi \rightarrow \mathrm{N}(0,1)$, where $\zeta=1 / 15$ and $\xi=11 / 6300$. The panel unit root tests indicate all the variables are integrated of order one.

The Hadri (2000) Lagrange multiplier (LM) test is closely related to that of the Carrion-i-Silvestre et al. test. It has the advantage of combining both stationary and non-stationary variables and permits a formulation for a residual-based LM test of stationarity. Hadri adopts the following representation:

$$
\mathrm{y}_{\mathrm{it}}=\mathrm{z}_{\mathrm{it}}{ }^{\prime} \gamma+\mathrm{r}_{\mathrm{it}}+\varepsilon_{\mathrm{it}}
$$

where $z_{i t}$ is the deterministic component, $r_{i t}$ is a random walk process defined as $r_{i t}=r_{i, t-1}+u_{i t}$, with $u_{i t} \rightarrow \operatorname{iid}\left(0, \sigma_{u}^{2}\right)$ and $\varepsilon_{i t}$ is a stationary process. The null hypothesis of trend stationarity corresponds to the hypothesis that the variance of the random walk is zero. The $y_{i t}$ process from above can be written as $y_{i t}=z_{i t}{ }^{\prime} \gamma+e_{i t}$, where:

$$
\mathrm{e}_{\mathrm{it}}=\sum_{\mathrm{j}=1}^{\mathrm{T}} \mathrm{u}_{\mathrm{ij}}+\varepsilon_{\mathrm{it}}
$$

The residuals from the above regression $\left(\mathrm{e}_{\mathrm{it}}\right)$ are obtained. This time the statistic can be written as:

$$
\mathrm{LM}=1 / \mathrm{N} \sum_{\mathrm{i}=1}^{\mathrm{N}}\left(\sum_{\mathrm{t}=1}^{\mathrm{T}} \mathrm{S}_{\mathrm{it}}{ }^{2} / \mathrm{T}^{2} / \sigma_{\varepsilon}^{2}\right)
$$

where $\sigma_{\varepsilon}^{2}$ is the consistent Newey and West (1987) estimate of the long-run variance of residuals, while $\mathrm{S}_{\mathrm{it}}$ and testing are defined as above. The LM statistic is consistent and has an asymptotic normal distribution as both $\mathrm{T}$ and $\mathrm{N} \rightarrow \infty$. The main advantage of this test is that the moments of the asymptotic distribution are exactly derived, while the disturbance terms can be heteroskedastic across i. Finally, it is also possible to allow for serial dependence substituting the assumption that the errors $\varepsilon_{\text {it }}$ are i.i.d. normally distributed over $t$ with the assumption that they satisfy the strong mixing regularity conditions of Phillips and Perron (1988). In this case we replace $\sigma_{\varepsilon}{ }^{2}$ by the long-run variance defined as:

$$
\sigma^{2}=1 / \mathrm{N} \sum_{\mathrm{i}=1}^{\mathrm{N}} \lim \mathrm{T}^{-1} \underset{\substack{\left(S_{i T}^{2}\right) \\ T \rightarrow \infty}}{\left(S^{2}\right.}
$$

A consistent estimator of the above variance is obtained using again the estimators provided by Newey and West (1994).

The results in Table 2 point out that the hypothesis that all the variables under study contain a unit root is accepted at the $1 \%$ significant level in all tests, suggesting that these variables are I(1). These findings accept the presence of cointegation, while Carrion-i-Silvestre et al. (2005) tests, which allow for multiple level shifts, thereby, accommodating general forms of cross-dependence through bootstrap methods, denote that no structural breaks are detected.

\subsection{Dynamic heterogeneity}

An issue that it is of major concern is the heterogeneity of the countries included in this data set. In the statistical framework of this study we first test for heterogeneity and then by controlling for it through appropriate techniques (Holtz-Eakin, 1986; Holtz-Eakin et al., 1985). The dynamic heterogeneity, i.e. variation of the intercept over countries and time, across a cross-section of the relevant variables can be investigated as follows. In the first step, an $\operatorname{ADF}(n)$ equation for each relationship in the panel is estimated; then, the hypothesis of whether regression parameters are equal across these equations is tested. Next, a similar test of parameter equality is performed by estimating an-order autoregressive model for each of the relationships under investigation. Standard Chow-type F tests under the null of parameter equality across all relationships are also 
performed. Heterogeneity in cross-sectional parameters is indicated if the results reject the null hypothesis. Finally, homogeneity error variance across groups is also examined as another measure of dynamic heterogeneity. White's tests for group-wise heteroscedasticity are employed to serve this objective. The results of this procedure are reported in Table 3. In all specifications the empirical findings indicate that the relationships under investigation are characterized by heterogeneity of dynamics and error variance across groups, supporting the employment of panel analysis.

\subsection{Panel cointegration and long-run estimates}

With the respective variables integrated of order one based, the heterogeneous panel cointegration test advanced by Pedroni $(1999,2004)$, which allows for cross-section interdependence with different individual effects, is performed as follows:

$$
S_{i t}=\alpha_{i t}+\delta_{i} t+\gamma_{1 i} D R_{i t}+\gamma_{2 i} Y_{i t}+\varepsilon_{i t}
$$

where $i=1 \ldots \ldots . . N$ for each country in the panel and $t=1 \ldots \ldots . . T$ refers to the time period. The parameters $\alpha_{i t}$ and $\delta_{i}$ allow for the possibility of country-specific fixed effects and deterministic trends, respectively. $\varepsilon_{i t}$ denotes the estimated residuals which represent deviations from the long-run relationship. To test the null hypothesis of no cointegration, $\rho_{i}=1$, the following unit root test is conducted on the residuals as follows:

$$
\varepsilon_{i t}=\rho_{i} \varepsilon_{i t-1}+w_{i t}
$$

Pedroni $(1999,2004)$ proposes two types of cointegration tests. First, the panel tests are based on the within dimension approach which includes four statistics: panel $\mathrm{v}$, panel $\rho$, panel PP, and panel ADF-statistics. These statistics essentially pool the autoregressive coefficients across different countries for the unit root tests on the estimated residuals. These statistics take into account common time factors and heterogeneity across countries. Second, the group tests are based on the between dimension approach which includes three statistics: group $\rho$, group PP, and group ADF-statistics. These statistics are based on averages of the individual autoregressive coefficients associated with the unit root tests of the residuals for each country in the panel. All seven tests are distributed asymptotically as standard normal. Table 4 reports both the within and between dimension panel cointegration test statistics. All seven test statistics reject the null hypothesis of no cointegration at the 1 percent significance level.

Given that we find evidence of cointegration, we next estimate the long-run effect of dependency ratio on savings rate. The results on the long-run coefficients are reported in Table 5. The long-run coefficient estimates show that in the long-run, the dependency ratio has a statistically significant negative effect on savings rates in our African country sample. This finding implies that the demographic structure plays an important role in explaining the long-run savings behavior in these countries, while the savings rate will increase when the non-working population size is decreasing.

An additional important result is the expected positive coefficient on the real per capita income variable, implying that economic growth is one of the most powerful determinants of savings over the long-run.

\subsection{Panel causality test results}

Given the variables are cointegrated, a panel vector error correction model (Pesaran et al. 1999) is estimated to perform Granger-causality tests. The Engle-Granger (1987) two-step procedure is undertaken by first estimating the long-run model specified in equation (12) in order to obtain the estimated residuals. Next, defining the lagged residuals from equation (12) as the error correction term, the following dynamic error correction model is estimated:

$$
\begin{aligned}
& \Delta S_{i t}=\alpha_{1 j}+\sum_{k=1}^{q} \theta_{11 i k} \Delta S_{i t-k}+\sum_{k=1}^{q} \theta_{12 i k} \Delta D R_{i t-k}+\sum_{k=1}^{q} \theta_{13 i k} \Delta Y K_{i t-k}+\lambda_{1 \mathrm{i}} \varepsilon_{\mathrm{it}-1}+\mathrm{u}_{1 \mathrm{it}} \\
& \Delta D R_{i t}=\alpha_{2 j}+\sum_{k=1}^{q} \theta_{21 i k} \Delta S_{i t-k}+\sum_{k=1}^{q} \theta_{22 i k} \Delta D R_{i t-k}+\sum_{k=1}^{q} \theta_{23 i k} \Delta Y_{i t-k}+\lambda_{2 \mathrm{i}} \varepsilon_{\mathrm{it}-1}+\mathrm{u}_{2 \mathrm{it}} \\
& \Delta Y_{i t}=\alpha_{3 j}+\sum_{k=1}^{q} \theta_{31 i k} \Delta S_{i t-k}+\sum_{k=1}^{q} \theta_{32 i k} \Delta D R_{i t-k}+\sum_{k=1}^{q} \theta_{33 i k} \Delta Y_{i t-k}+\lambda_{3 \mathrm{i}} \varepsilon_{\mathrm{it}-1}+\mathrm{u}_{3 \mathrm{it}}
\end{aligned}
$$

where $\Delta$ is the first-difference operator; $q$ is the lag length set at two based on likelihood ratio tests; and $u$ is the serially uncorrelated error term. With respect to equations (14)-(16), short-run causality is determined by the statistical significance of the partial F-statistics associated with the corresponding right hand side variables. Long-run causality is revealed by the statistical significance of the respective error correction terms using a 
t-test.

Table 6 reports the results of the short-run and long-run causality tests. We focus on the savings equation (14) in which the dependency ratio has a negative and statistically significant impact on savings, while income has a positive and statistically significant impact on savings impact, implying that increased age dependency leads to lower savings in the short-run. These findings are consistent with the life-cycle predictions and also Rossi's (1989) study for developing countries, but contradict with Gupta (1971) who argued that dependency ratio does not appear to play any role in the low income per capita countries. Moreover, the error correction term is statistically significant at the 1 percent level, but with a relatively high speed of adjustment to long-run equilibrium.

\section{Concluding remarks and implications}

The life cycle model suggests that the age structure of the population has a significant impact on the saving rate and in particular that the dependency ratio has a negative impact on the savings rate. The primary goal of this paper was to test, through the panel data approach, whether such predictions hold in the context of African countries. We investigated this issue for a group of 16 African countries. We found a cointegration relationship between savings rate, the dependency ratio and per capita income. The results from causality tests revealed that dependency rate negatively caused savings rate. Therefore, a decrease in the age dependency ratio increases long-run savings rates. This suggests that policies that lower the dependency ratio will have a positive impact on savings rates.

Overall, our results display that we cannot ignore the fact that demographics do matter for savings behavior in African countries. Our findings contain pessimism regarding the possibility of increasing the savings rates of some African countries, unless dependency rates are reduced. Most developing countries are at an earlier stage in the demographic transition induced by lower rates of fertility and mortality. However, the dependency ratios remained high compared to Asian countries. Even so, the decline in fertility is good news for savings and economic growth. Programs to make available less costly and painful birth-reducing methods should be expanded is some areas, particularly in rural areas, where the motivation for fewer births is not yet present. In these areas, it also should be beneficial to create conditions for new attitudes toward births reduction.

Before closing, we offer some topics deserving future research. First, in this study we have examined the relationship between the dependence ratio and savings rate within a trivariate setting. What the evidence may suggest is that there may be a number of factors at work that differ significantly across countries that account for the findings of this study. Reexamining the topic within a multivariate framework by incorporating some of these factors may be a line of inquiry that can help us understand the relationship between savings and demographics. Second, another interesting research topic to be examined in depth is the impact of income on the effect of dependency ratio on savings by using non-linear models. It is argued that demographic factors, like the dependency ratio, become operative and significant only when per capita income reaches a level where it can provide more than a minimum level of living, thus generating potential savings. Finally, the paper can go through the quantification of active and inactive demographic classes by having reference to age intervals less wide.

\section{References}

Altonji, J. G., Hayashi, F., \& Kotlikoff, L. J. (1997). Parental Altruism and Inter Vivos Transfers: Theory and Evidence. Journal of Political Economy, 105, 1121-1166. http://dx.doi.org/10.1086/516388

Anoruo, E., \& Ahmad, Y. (2001). Causal Relationship between Domestic Savings and Economic Growth: Evidence from Seven African Countries. African Development Bank, Blackwell Publishers, Oxford.

Attias-Donfut, C. (1995). Les Solidarites Enlre Generations: Vieil/esse, Families, Etat. Paris, Nathan.

Baharumshah, A. Z., Thanoon, M. A., \& Rashid, S. (2003). Saving Dynamics in the Asian Countries. Journal of Asian Economics, 13, 827-845. http://dx.doi.org/10.1016/S1049-0078(02)00187-2

Bloom, D. E., \& Williamson, J. G. (1998). Demographic Transition and Economic Miracles in Emerging Asia. World Bank Economic Review, 12, 419-455.

Brander, J. A., \& Dowrick, S. (1994). The role of Fertility and Population in Economic Growth. Journal of Population Economics, 7, 1-25. http://dx.doi.org/10.1007/BF00160435

Carrion-i-Silvestre, J. L., del Barrio-Castro, T., \& Lopez-Bazo, E. (2005). Breaking the Panels: An Application to GDP per Capita. Econometrics Journal, 8, 159-175. http://dx.doi.org/10.1111/j.1368-423X.2005.00158.x

Deaton, A. S. (1992). Saving and Income Smoothing in Cote d'Ivoire. Journal of African Economics, 1, 1-24. 
Deaton, A. S. (1990). Savings in Developing Countries: Theory and Review. World Bank Economic Review, 4, 61-95.

Deaton, A. S., \& Paxson, C. H. (1997). The Effects of Economic and Population Growth on National Saving and Inequality. Demography, 34, 97-114. http://dx.doi.org/10.2307/2061662

Edwards, S. (1996). Why are Latin America's Savings Rates so Low? An International Comparative Analysis. Journal of Development Economics, 51, 5-44. http://dx.doi.org/10.1016/S0304-3878(96)00424-5

Elbadawi, I. A., \& Mwega, F. M. (2000). Can Africa's Saving Collapse be Reversed?. The World Bank Economic Review, 14, 415-443.

Engle, R. F., \& Granger, C. W. J. (1987). Cointegration and Error Correction: Representation, Estimation, and Testing. Econometrica, 55, 251-276. http://dx.doi.org/10.2307/1913236

Escobar, A., \& Cardenats, M. (1998). Saving Determinants in Colombia: 1925-1994. Journal of Development Economics, 57, 5-44.

Faruquee, H., \& Husain, A. M. (1998). Saving Trend in Southeast Asia: A Cross-Country Analysis. Asian Economic Journal, 12, 195-217. http://dx.doi.org/10.1111/1467-8381.00060

Graham, J. W. (1987). International Differences in Saving Rates and the Life-Cycle Hypothesis. European Economic Review, 31, 1509-1529. http://dx.doi.org/10.1016/S0014-2921(87)80024-7

Goldberger, A. S. (1973). Dependency Rates and Saving Rates: Comment. American Economic Review, 63, 232-233.

Gupta, K. L. (1971). Dependency Rates and Savings Rates: Comment. American Economic Review, 61, 469-471.

Hadri, K. (2000). Testing for Stationarity in Heterogeneous Panel Data. Econometric Journal, 3, 148-161. http://dx.doi.org/10.1111/1368-423X.00043

Higgins, M., \& Williamson, J. G. (1997). Age Structure Dynamics in Asia and Dependence on Foreign Capital. Population and Development Review, 23, 261-293. http://dx.doi.org/10.2307/2137546

Holtz-Eakin, D. (1986). Testing for Individual Effects in Dynamic Models Using Panel Data. NBER Technical Paper Series, No. 57.

Holtz-Eakin, D., Newey, W., \& Rosen, H. (1985). Implementing Causality Tests with Panel Data with an Example from Local Public Finance. NBER Technical Working Paper, No. 48.

Horioka, C. Y. (1997). A Cointegration Analysis of the Impact of the Age Structure of the Population on the Household Saving Rate in Japan. Review of Economics and Statistics, 79, 511-516. http://dx.doi.org/10.1162/rest.1997.79.3.511

Hugon, P. (1993). L 'economie de I'Afrique. Paris, La Decouverte.

Husain, A. M. (1995). Long-Run Determinants of Private Saving Behavior in Pakistan. The Pakistan Development Review, 34, 1057-1066.

Ikhide, S. I. (1996). Commercial Bank Offices and the Mobilisation of Private Savings in Selected Sub-Saharan African Countries. Journal of Development Studies, 33, 117-132. http://dx.doi.org/10.1080/00220389608422456

Im, K. S., Pesaran, M. H., \& Shin, Y. (2003). Testing for Unit Roots in Heterogeneous Panels. Journal of Econometrics, 115, 53-74. http://dx.doi.org/10.1016/S0304-4076(03)00092-7

Kelley, A. C., \& Schmidt, R. M. (1996). Saving, Dependency and Development. Journal of Population Economics, 9, 365-386. http://dx.doi.org/10.1007/BF00573070

Leff, N. H. (1969). Dependency Rates and Savings Rates. American Economic Review, 59, 886-896.

Levin, R., \& Lin, C. F., \& James Chu, C. (2002). Unit Root Tests in Panel Data: Asymptotic and Finite-Sample Properties. Journal of Econometrics, 108, 1-24. http://dx.doi.org/10.1016/S0304-4076(01)00098-7

Loayza, N., Schmidt-Hebbel, K., \& Serven, L. (2000). What Drives Private Saving Across the World? Review of Economics and Statistics, 82, 165-181. http://dx.doi.org/10.1162/003465300558678

Maddala, G. S., \& Wu, S. (1999). A Comparative Study of Unit Root Tests with Panel Data and a New Simple Test. Oxford Bulleting of Economics and Statistics, 61, 631-652. http://dx.doi.org/10.1111/1468-0084.61.s1.13

Mason, A. (2001). Population Change and Economic Development in East Asia. Stanford, CA: Stanford University Press. 
Mason, A. (1988). Saving, Economic-Growth, and Demographic Changes. Population and Development Review, 14, 113-144. http://dx.doi.org/10.2307/1972502

Masson, P. R., \& Tryon, R. W. (1990). Macroeconomic Effects of Projected Population Aging in Industrial Countries. IMF Staff Papers, 37, 453-485. http://dx.doi.org/10.2307/3867261

Masson, P. R., Bayoumi, T., \& Samiei, H. (1998). International Evidence on the Determinants of Private Saving. The World Bank Economic Review, 12, 483-501.

Modigliani, F., \& Cao, S. L. (2004). The Chinese Saving Puzzle and the Life-Cycle Hypothesis. Journal of Economic Literature, 42, 145-170. http://dx.doi.org/10.1257/002205104773558074

Modigliani, F. (1970). The Life-Cycle Hypothesis of Saving and Inter-Country Differences in the Saving Ratio. In W. A. Eltis, M. F. Scott, and J. N. Wolfe (eds.), Induction, Trade and Growth: Essays in Honor of Sir Roy Harrod. Clarendon Press, London.

Muradoglu, G., \& Taskin, F. (1996). Differences in Household Savings Behavior: Evidence from Industrial and Developing Countries. The Developing Economies, 34, 132-153.

Mwega, F. (1997). Saving in Sub-Saharan Africa: A Comparative Analysis. Journal of African Economies, 6, Supplement, 199-228.

Newey, W. K., \& West, K. D. (1994). Automatic Lag Selection in Covariance Matrix Estimation. Review of Economic Studies, 61, 631-654. http://dx.doi.org/10.2307/2297912

Newey, W., \& West, K. (1987). Hypothesis Testing with Efficient Method of Moments Estimation. International Economic Review, 28, 777-787. http://dx.doi.org/10.2307/2526578

Nissanke, M., \& Aryeetey, E. (1998). Financial Integration and Development, Liberalization and Reform in Sub-Saharan Africa. ODI and Routledge, London.

Nugent, J. B. (1985). The Old-Age Security Motive for Fertility. Population and Development Review, 11, 75-97. http://dx.doi.org/10.2307/1973379

Pedroni, P. (2004). Panel Cointegration: Asymptotic and Finite Sample Properties of Pooled Time Series Tests with an Application to the PPP Hypothesis: New Results. Econometric Theory, 20, 597-627. http://dx.doi.org/10.1017/S0266466604203073

Pedroni, P. (1999). Critical Values for Cointegration Tests in Heterogeneous Panels with Multiple Regressors. Oxford Bulletin of Economics and Statistics, 61, 653-670. http://dx.doi.org/10.1111/1468-0084.61.s1.14

Pesaran, H. M., Shin, Y., \& Smith, R. P. (1999). Pooled Mean Group Estimation of Dynamic Heterogeneous Panels. Journal of the American Statistical Association, 94, 621-634. http://dx.doi.org/10.2307/2670182

Phillips, P. C. B., \& Perron, P. (1988). Testing for a Unit Root in Time Series Regression. Biometrika, 75, 335-346. http://dx.doi.org/10.1093/biomet/75.2.335

Prema-Chandra, A., \& Pnag-Long, T. (2003). Determinants of Household Saving in Taiwan: Growth, Demography and Public Policy. The Journal of Development Studies, 39, 65-88. http://dx.doi.org/10.1080/00220380412331333149

Ram, R. (1982). Dependency Rates and Saving Rates: A New international Cross-Section Study. American Economic Review, 72, 537-544.

Rossi, N. (1989). Dependency Rates and Private Savings Behavior in Developing Countries. International Monetary Fund Staff Paper, 36, 166-181. http://dx.doi.org/10.2307/3867173

Serres, A., \& Pelgrin, F. (2003). The Decline in Private Saving Rates in the 1990s in OECD Countries: How Much can be Explained by Non-Wealth Determinants? OECD Economic Studies, 36,117-153.

Thornton, J. (2001). Age Structure and Personal Saving in the United States, 1956-1995. Southern Economic Journal, 68, 166-170. http://dx.doi.org/10.2307/1061519

World Bank (2002). Adjustment in Africa: Reforms, Results and the Road Ahead. Policy Research Report, Oxford University Press, London and New York. 
Table 1. Summary statistics of variables of interest

\begin{tabular}{|c|c|c|c|c|c|c|c|c|c|}
\hline & & \multicolumn{2}{|c|}{ SAVGDP } & & & \multicolumn{2}{|c|}{ AGERATIO } & & \\
\hline Country & Min & Mean & SD & Max & Min & Mean & SD & Max & Correlation \\
\hline Benin & -12.350 & 1.73 & 3.84 & 6.94 & 88.36 & 96.15 & 3.15 & 100.15 & -0.21 \\
\hline Burkina Faso & -8.027 & 1.74 & 4.76 & 11.58 & 80.10 & 96.41 & 8.87 & 106.15 & $0.36^{*}$ \\
\hline Cameroon & 10.760 & 18.93 & 4.95 & 29.09 & 82.12 & 89.98 & 4.59 & 95.98 & $0.65^{*}$ \\
\hline Cote d'lvoire & 10.380 & 22.93 & 5.94 & 33.62 & 82.22 & 90.48 & 3.62 & 95.94 & $-0.37^{*}$ \\
\hline Ghana & 1.250 & 8.26 & 3.81 & 17.13 & 74.47 & 88.00 & 4.70 & 92.55 & 0.01 \\
\hline Kenya & 9.080 & 16.91 & 4.33 & 27.02 & 82.89 & 103.94 & 9.92 & 112.53 & $0.69^{*}$ \\
\hline Mali & -4.610 & 4.81 & 6.33 & 14.04 & 89.22 & 101.27 & 6.78 & 109.15 & $0.26^{* *}$ \\
\hline Mauritania & -33.260 & 11.58 & 23.63 & 88.86 & 78.33 & 88.53 & 3.99 & 94.20 & $0.31^{*}$ \\
\hline Niger & -1.640 & 5.39 & 4.41 & 17.69 & 95.81 & 102.38 & 2.28 & 104.97 & 0.04 \\
\hline Nigeria & 3.480 & 20.09 & 10.18 & 42.32 & 86.25 & 91.85 & 2.64 & 95.97 & $0.36^{*}$ \\
\hline Senegal & -9.100 & 6.18 & 4.84 & 14.36 & 84.21 & 93.98 & 4.60 & 99.29 & -0.17 \\
\hline Sierra Leone & -13.26 & 7.68 & 10.09 & 27.31 & 74.62 & 80.15 & 3.25 & 85.48 & $-0.68^{*}$ \\
\hline South Africa & 16.76 & 24.84 & 4.96 & 37.88 & 58.35 & 74.97 & 9.92 & 85.49 & $0.78^{*}$ \\
\hline Togo & -2.160 & 14.62 & 11.04 & 53.50 & 87.27 & 93.97 & 3.29 & 98.72 & 0.13 \\
\hline Zambia & 0.320 & 22.18 & 14.52 & 50.94 & 90.16 & 95.12 & 3.07 & 100.36 & 0.01 \\
\hline Zimbabwe & 0.620 & 15.92 & 5.33 & 24.74 & 75.50 & 97.46 & 10.45 & 107.86 & $0.54^{*}$ \\
\hline$*(* *)$ indicates statistical significance at the 5\% (10\%) level. & & & & \\
\hline
\end{tabular}


Table 2. Panel unit root tests

\begin{tabular}{|c|c|c|c|}
\hline \multirow[t]{7}{*}{ IPS Tests } & Variables & Without Trend & With Trend \\
\hline & $\mathrm{S}$ & $-1.37(3)$ & $-1.78(3)$ \\
\hline & $\Delta \mathrm{S}$ & $-5.61(2)^{*}$ & $-5.51(1)^{*}$ \\
\hline & $\mathrm{D}$ & $-1.40(2)$ & $-1.77(2)$ \\
\hline & $\Delta \mathrm{D}$ & $-5.47(1)^{*}$ & $-5.68(1)^{*}$ \\
\hline & $\mathrm{Y}$ & $-1.33(4)$ & $-1.64(4)$ \\
\hline & $\Delta \mathrm{Y}$ & $-5.36(2)^{*}$ & $-5.77(3)^{*}$ \\
\hline \multirow[t]{7}{*}{ LLC Tests } & Variables & With Trend & \\
\hline & $\mathrm{S}$ & -1.22 & \\
\hline & $\Delta \mathrm{S}$ & $-9.63 *$ & \\
\hline & $\mathrm{D}$ & -1.42 & \\
\hline & $\Delta \mathrm{D}$ & $-9.47 *$ & \\
\hline & $\mathrm{Y}$ & -1.34 & \\
\hline & $\Delta \mathrm{Y}$ & $-9.22 *$ & \\
\hline \multirow[t]{7}{*}{ Handri (hom) Tests } & Variables & With Trend & \\
\hline & $\mathrm{S}$ & $12.27 *$ & \\
\hline & $\Delta \mathrm{S}$ & 1.25 & \\
\hline & $\mathrm{D}$ & $11.23^{*}$ & \\
\hline & $\Delta \mathrm{D}$ & 1.19 & \\
\hline & $\mathrm{Y}$ & $25.16^{*}$ & \\
\hline & $\Delta \mathrm{Y}$ & 1.35 & \\
\hline \multirow[t]{7}{*}{ Handri (het) Tests } & Variables & With Trend & \\
\hline & $\mathrm{S}$ & $9.48 *$ & \\
\hline & $\Delta \mathrm{S}$ & 0.52 & \\
\hline & $\mathrm{D}$ & $19.36^{*}$ & \\
\hline & $\Delta \mathrm{D}$ & 1.37 & \\
\hline & $\mathrm{Y}$ & $24.46^{*}$ & \\
\hline & $\Delta \mathrm{Y}$ & 1.21 & \\
\hline \multirow{4}{*}{$\begin{array}{c}\text { Carrion-i-Silvestre } \\
\text { et al. (no breaks, } \\
\text { homogeneous) } \\
\text { Tests }\end{array}$} & Variables & & \\
\hline & $\mathrm{S}$ & 20.83 & \\
\hline & $\mathrm{D}$ & 9.96 & \\
\hline & $\mathrm{Y}$ & 17.82 & \\
\hline \multirow{4}{*}{$\begin{array}{l}\text { Carrion-i-Silvestre } \\
\text { et al. (no breaks, } \\
\text { heterogeneous) } \\
\text { Tests }\end{array}$} & Variables & & \\
\hline & $\mathrm{S}$ & 15.25 & \\
\hline & $\mathrm{D}$ & -9.77 & \\
\hline & $\mathrm{Y}$ & 17.51 & \\
\hline \multirow[t]{7}{*}{ Fisher-ADF Tests } & Variables & & \\
\hline & $\mathrm{S}$ & 14.68 & \\
\hline & $\Delta \mathrm{S}$ & $95.55^{*}$ & \\
\hline & $\mathrm{D}$ & 20.23 & \\
\hline & $\Delta \mathrm{D}$ & $141.98 *$ & \\
\hline & $\mathrm{Y}$ & 26.02 & \\
\hline & $\Delta \mathrm{Y}$ & $167.33 *$ & \\
\hline \multirow[t]{7}{*}{ Fisher-PP Tests } & Variables & & \\
\hline & $\mathrm{S}$ & 22.26 & \\
\hline & $\Delta \mathrm{S}$ & $142.48 *$ & \\
\hline & $\mathrm{D}$ & 17.89 & \\
\hline & $\Delta \mathrm{D}$ & $162.18^{*}$ & \\
\hline & $\mathrm{Y}$ & 24.22 & \\
\hline & $\Delta \mathrm{Y}$ & $177.12 *$ & \\
\hline
\end{tabular}

Numbers in parentheses are the augmented lags included in the unit root test, while $\Delta$ denotes first differences.

* denotes statistical significance at $1 \%$ 
Table 3. Tests of Dynamic Heterogeneity across Groups

\begin{tabular}{|c|c|c|c|}
\hline Specification & $\operatorname{ADF}(3)$ & AR(3) & White's Test \\
\hline S-D-Y & $45.02^{*}$ & $46.55^{*}$ & $75.63^{*}$ \\
\hline
\end{tabular}

$\mathrm{ADF}(3)$ reports the parameter equality test (F-test) across all relationships in the panel. AR(3) displays the F-test of parameter equality conducted in a third-order autoregressive model of the relationships. White's test reports the White's test of equality of variances across the investigated relationships in the panel. $\Delta$ denotes first differences.

* denotes statistical significance at $1 \%$.

Table 4. Panel cointegration tests

\begin{tabular}{|l|c|c|c|}
\hline $\begin{array}{l}\text { Within Dimension } \\
\text { Test Statistics: }\end{array}$ & Total capital stock & $\begin{array}{c}\text { Between Dimension } \\
\text { Test Statistics: }\end{array}$ & Total assets \\
\hline Panel v-statistic & $40.54750^{*}$ & Group $\rho$-statistic & $-42.64393^{*}$ \\
\hline Panel $\rho$-statistic & $-42.36608^{*}$ & Group PP-statistic & $-41.20745^{*}$ \\
\hline Panel PP-statistic & $-41.03739^{*}$ & Group ADF-statistic & $-4.62378^{*}$ \\
\hline Panel ADF-statistic & $-4.67155^{*}$ & & \\
\hline
\end{tabular}

Of the seven tests, the panel v-statistic is a one-sided test where large positive values reject the null hypothesis of no cointegration whereas large negative values for the remaining test statistics reject the null hypothesis of no cointegration. Critical values at the 1 percent significance level denoted by an asterisk: panel v (24.56), panel $\rho$ (-17.60), panel PP and group PP (-25.59), panel ADF (-2.97), group $\rho$ (-21.12), and group ADF (-3.18).

Table 5. Panel cointegration estimates

\begin{tabular}{|llll|}
\hline $\begin{array}{c}\mathrm{S}=0.097 \\
(5.67)^{*} \quad(-9.62)^{*}\end{array}$ & & \\
\hline Diagnostics: & & & \\
\hline Adj. $\mathrm{R}^{2}=0.86$ & $\mathrm{LM}=1.13$ & RESET $=1.97$ & $\mathrm{HE}=1.32$ \\
& {$[0.46]$} & {$[0.19]$} & {$[0.28]$} \\
\hline
\end{tabular}

t-statistics are reported in parentheses and probability values in brackets. LM is the LaGrange multiplier test for serial correlation. RESET is the misspecification test. HE is White's heteroskedasticity test. Significance at the 1 percent level denoted by an asterisk.

Table 6. Panel causality tests

\begin{tabular}{|c|c|c|c|c|}
\hline \multirow[t]{2}{*}{ Dependent Variable } & \multicolumn{4}{|c|}{ Sources of Causation (Independent Variables) } \\
\hline & \multicolumn{2}{|c|}{ Short-run } & \multicolumn{2}{|l|}{ Long-Run } \\
\hline \multirow[t]{3}{*}{ (13) $\Delta S$} & $\Delta \mathrm{S}$ & $\Delta \mathrm{DR}$ & $\Delta \mathrm{Y}$ & ECT \\
\hline & - & $36.19(-0.279)$ & $1.15(0.298)$ & -0.155 \\
\hline & - & {$[0.00]^{\mathrm{a}}[0.00]^{*}$} & {$[0.39][0.01]^{*}$} & {$[0.00]^{*}$} \\
\hline
\end{tabular}

Partial F-statistics reported with respect to short-run changes in the independent variables. The sum of the lagged coefficients for the respective short-run changes is denoted in parentheses. ECT represents the coefficient of the error correction term. Probability values are in brackets and reported underneath the corresponding partial F-statistic and sum of the lagged coefficients, respectively. Significance at the 1 percent level is denoted by an asterisk. 